\title{
Conceptualizing Emotions through Metaphors in Fortress Besieged
}

\author{
Pengju $\mathrm{Du}^{1}$ \\ ${ }^{1}$ Department of Foreign Language, Yulin University, Shaanxi, China \\ Correspondence: Pengju Du, Department of Foreign Language, Yulin University, No.4 Chongwen West Road, \\ Yulin 719000, Shaanxi, China. Tel: 86-912-389-3982. E-mail: pengju.du@aliyun.com
}

\author{
Received: October 14, 2014 Accepted: November 10, 2014 Online Published: January 27, 2015 \\ doi:10.5539/ijel.v5n1p53 URL: http://dx.doi.org/10.5539/ijel.v5n1p53
}

The research is financed by Yulin University. No. $14 G K 09$.

\begin{abstract}
Using conceptual metaphor theory (CMT), this article examines how metaphors of emotion are constituted in the Chinese novel Fortress Besieged (Wei Cheng). The article makes two important contributions to CMT and cognitive linguistics: a) it investigates the universality thesis of CMT, by assessing its tenets in relation to the Chinese language; and b) it analyses the textual use of metaphors of emotion, by drawing from a corpus extracted from a full-length literary narrative. The article considers the role of culture and geography in the development of language-specific conceptual metaphors, and focuses on the emotions of happiness (喜), anger (怒), sadness (悲), and love (爱).
\end{abstract}

Keywords: emotions, conceptual metaphors, Fortress Besieged

\section{Introduction}

Traditionally metaphor has been viewed as a rhetorical and stylistic device. However, the publication of Lakoff and Johnson's seminal book Metaphors We Live By in 1980 marked the beginning of the cognitive era in metaphor study. These authors put forward the idea of "Conceptual Metaphor Theory" (CMT) for the first time, and claimed that "metaphor is pervasive in everyday life, not just in language but in thought and action. Our ordinary conceptual system, in terms of which we both think and act, is fundamentally metaphorical in nature." (p. 3). Therefore, instead of being an ornament to language, metaphor was promoted to a powerful tool that helps humans cognize the world.

Emotions, as an important aspect of human experience, are one of the focuses of studying human cognition. Studies on emotion have increased substantially in recent years and have become part of the subject matter of various scientific disciplines, including anthropology (Lutz, 1988; Lutz \& White, 1986; Milton \& Svašek, 2005), neurobiology (Heberlein \& Adolphs, 2007; LeDoux, 1986, 1996), psychology (Bowles, 2006; Plutchik, 1994), philosophy (Goldie, 2000, 2010; Solomon, 1993) and linguistics (Athanasiadou \& Tabakowska, 1998; Barcelona, 1986, 1995; J. Chen, 2007; King, 1989; Kövecses, 1986, 1988, 1990, 1991, 1995a, 1995b, 1998, 2000, 2002, 2005, 2008; Lakoff and Johnson, 1980; Lakoff \& Kövecses, 1987; Niemeier \& Dirven, 1997; Palmer \& Occhi, 1999; Tissari, 2001, 2006a, 2006b, 2008, 2010; Wierzbicka, 1992, 1998, 1999, 2009; Yu, 1995, 1998, 2002). In linguistics, the development of cognitive linguistics has progressed research in this area. A number of cognitive linguistic studies (Barcelona, 2000, 2002; Fludernik, 2011; Gibbs, 1994, 2006; Gibbs \& Steen, 1999; Johnson, 1987; Kövecses, 1986, 1988, 1990, 2000, 2002, 2005; Lakoff, 1990; Lakoff \& Johnson, 1980; Lakoff \& Turner, 1989; Turner, 1987) show that metaphor plays a significant role in conceptualizing emotions.

This paper will apply CMT to studying the emotion concepts in a modern Chinese novel Fortress Besieged. The objectives of the paper are to identify the categories of metaphors through which emotions are represented in Fortress Besieged, to test the usefulness of CMT for the study of literary texts and to contribute to the investigation of the universality of emotion metaphors from the Chinese perspective. A central claim of the studies conducted on the function of metaphor in conceptualizing emotions (Kövecses, 1986, 1988, 1990, 1991, 2000; Lakoff, 1987; Lakoff \& Johnson, 1980; Lakoff \& Kövecses, 1987) is that human emotions, which are abstract in nature, are to a great extent conceptualized through metaphors grounded in bodily experiences. While this claim is meant to be universal, the evidence supporting it is mainly derived from English. Thus, this paper 
attempts to contribute to this claim from the Chinese perspective in order to find out whether emotions are also conceptualized metaphorically in a Chinese novel Fortress Besieged.

The paper will focus on "basic emotions" (D’Andrade, 1995; Ekman, 1999). Kövecses (1990) notes the "basic" in "basic emotions" has two implications: one is that they tend to be universal and form the most frequently mentioned emotion types; the other is that a particular emotion type can be judged to be more prototypical than another, such as happiness and anger are viewed as better examples of emotion than, say, calmness and boredom. Thus, this paper will select “happiness (喜), anger (怒), sadness (悲) and love (爱)” as the research subjects.

\section{Conceptual Metaphor Theory}

Conceptual Metaphor Theory, sometimes called Cognitive Metaphor Theory, argues that metaphor does not only denote a figure of speech but also refers to a basic way by which speakers understand one conceptual domain in terms of another. As Barcelona (2000, p. 3) defines it, metaphor is "the cognitive mechanism whereby one experiential domain is partially 'mapped', i.e., projected, onto a different experiential domain, so that the second domain is partially understood in terms of the first one. The domain that is mapped is called the source or donor domain, and the domain onto which the source is mapped is called the target or recipient domain". For example, the source domain WAR which is more concrete and easy to understand is mapped onto the target domain ARGUMENT, which is more abstract, via the conceptual metaphor ARGUMENT IS WAR. At the same time, the metaphorical mappings are not arbitrary, for they are deeply rooted in our bodily experience. As the philosophical basis of cognitive linguistics - "experiential realism" claims, "conceptual structure is meaningful because it is embodied, that is, it arises from and is tied to our preconceptual bodily experience" (Lakoff, 1987, p. 267).

Conceptual metaphor is an important concept in cognitive linguistics. Yu (1998, p. 16), however, points out that a unique feature of CMT is that "it makes a remarkable distinction between conceptual metaphors and metaphorical expressions". Metaphorical expression is the linguistic manifestation of conceptual metaphor, whereas a conceptual metaphor can be expressed in several different metaphorical expressions. In other words, as Lan (2005) notes, the existence of metaphorical expressions is due to a metaphorical conceptual model existing in human conceptual systems.

Lakoff and Johnson (1980) point out that according to the cognitive functions that they perform, i.e., the way in which metaphors are used to help humans possess a better way to understand the world, conceptual metaphors can be classified into three general kinds: structural metaphor, ontological metaphor, and orientational metaphor. Structural metaphors refer to "those cases where one concept is metaphorically structured in terms of another, that is, structural metaphors allow speakers to use one highly structured and clearly delineated concept to partially structure another" (Lakoff \& Johnson, 1980, p. 61), such as the above mentioned conceptual metaphor ARGUMENT IS WAR. In ontological metaphor, "[o]ur experiences provide the basis for an extraordinarily wide variety of ontological metaphors, that is, ways of viewing events, activities, emotions, ideas, etc., as entities and substances" (Lakoff \& Johnson, 1980, p. 25). The most typical and representative metaphor in ontological metaphor is the container metaphor, such as ANGER IS A HOT FLUID IN A CONTAINER. Orientational metaphor is to do with basic human spatial orientations: "up-down, in-out, front-back, on-off, deep-shallow, center-periphery" (Lakoff \& Johnson, 1980, p. 14), for example, HAPPINESS IS UP.

\section{A Brief Introduction to Fortress Besieged}

Fortress Besieged (Chinese name: 《围城》Wei Cheng) was written by Qian Zhongshu and published in 1947. Qian Zhongshu is a well-known modern Chinese literary scholar and writer and "ranks among the foremost twentieth-century Chinese novelists" (Kelly \& Mao, 2003, p. iii). He is one of the few acknowledged masters of written vernacular Chinese in the 20th century (Hsia, 1999) and one of the best-known Chinese writers in the West (Zhang, 1985). Fortress Besieged, as Qian's representative work, is one of the most popular contemporary Chinese novels in China. Its story satirizes the behavior and attitudes of middle-class Chinese society in the late 1930s and the writing is full of detailed and ethnographically rich depiction of emotions. Fortress Besieged is characterized by the extensive use of metaphor and extracts from the novel have entered the modern Chinese idiomatic lexicon. For example, "Clayton University" is used as an idiom meaning an illegitimate academic institution, and "Wei Cheng" has become a proverb in modern Chinese meaning a dilemma situation. Besides its great reputation in China, Fortress Besieged is also internationally famous, and has been translated into many different languages, including English, Russian, French, Japanese, German, Spanish and Korean. 


\section{Identification of Metaphorical Expressions of Emotions}

Ortony, Clore and Collins (1988) note that the most readily available access people have to emotion is through language. Also, Allan (1995) states that one of the most important sources of information for studying emotion concepts is linguistic analysis. Therefore, this paper will use linguistic qualitative analysis, in particular a close-reading text analysis, as its main method. More specifically, how the emotions are conceptualized will be uncovered through a detailed study of the linguistic expressions used to express the emotions.

Due to the fact that talking about emotions does not necessarily require the emotions to be named, I conducted a hand search approach of Fortress Besieged, and extracted a corpus of 608 metaphorical expressions of happiness, anger, sadness, and love. All these metaphorical expressions were analyzed following CMT as a model to show how these emotions are conceptualized through metaphors in Fortress Besieged.

Taking Pragglejaz Group's metaphor identification method (2007) as a main guide, I identified the metaphorical expressions of emotions in Fortress Besieged in this paper by:

1) Reading the whole novel first in order to become familiar with its story and context.

2) Reading the novel again sentence by sentence and taking each chapter as a unit to find and determine the emotions and their linguistic expressions.

3) Establishing and checking the meaning of each lexical unit in each linguistic expression in the context, and considering the collocations before and after the lexical unit.

4) Determining if the lexical unit has a more ordinary meaning in other contexts than the one in the novel context. More ordinary meanings refer to:

- A more basic and specific meaning which is easier to come into the mind;

- A widely known and accepted meaning in daily life;

- The first or second definition in the contemporary dictionary (Note 1).

5) Comparing the contextual meaning of each lexical unit with its ordinary meaning to see whether the contextual meaning is different from the ordinary meaning but can be understood in comparison with it.

6) If the answer to 5) was positive, then this linguistic expression was confirmed as a metaphorical expression.

As regards the way metaphors are presented in this paper, in translating the metaphorical expressions of emotions into English, each expression is first provided with a word-for-word translation, which is then followed by a freer translation. The expressions are first translated literally with a view to revealing the Chinese thought patterns involved in conceptualizing emotions.

\section{Conceptualization of Emotions in Fortress Besieged}

\subsection{Happiness}

140 metaphorical expressions of happiness in Fortress Besieged were found. Through my analysis, 15 typical conceptual metaphors were employed to conceptualize happiness, which are listed in Table 1.

Table 1. Typical conceptual metaphors of happiness in Fortress Besieged

\begin{tabular}{ll}
\hline Target Domain & Source Domains \\
\hline & Up \\
& Light \\
& Red \\
Happiness & Hot and noisy \\
& Light (Not heavy) \\
& Sweet \\
& Full \\
& A game \\
& Vitality \\
& Unity \\
Soft \\
Loose \\
Pressure \\
A substance in a container \\
Heart
\end{tabular}


Following are some characteristic examples of how happiness is conceptualized through these typical metaphors in Fortress Besieged:

\section{HAPPINESS IS UP}

(1) “他父亲收到这信, 证明自己的威严远及于几千里外, 得意非凡, 兴头上汇给儿子一笔钱, 让他买补 药。”( p. 20)

“.......spirit-head-up......"

"When his father received the letter, which proved his authority had reached across several thousands miles, he was extremely satisfied. He, in high spirits, sent his son a sum of money to let him buy tonic medicine."

(2) “三闾大学的电报, 家里还没知道, 报告了父亲母亲, 准使他们高兴, 他们高兴头上也许心气宽和, 不会细密地追究盘问。”(p. 226)

“......high-spirit, .....high-spirit-head-up......"

"His family still didn't know about the telegram from San Lu University. If he tells this to his parents, they would certainly be happy, and in their high spirits they might be more magnanimous and not ask him too much."

HAPPINESS IS LIGHT

(3) “高松年看方鸿渐和颜悦色, 不相信世界上会有这样脾气好或城府深的人.....” (p. 388)

“...... calm-face-nice-color, ......."

"When Gao Songnian saw Fang Hongjian's pleasant face, he didn't believe there is such a good- natured or a shrewd and deep person in the world......"

HAPPINESS IS RED

(4) “李梅亭得到通知, 忙把压在裖子下的西装裤子和领带取出, 早刮过脸, 皮破了好几处, 倒也红光满 面。”( p. 328)

“...... red-light-full-face"

"When Li Meiting got the news, he quickly took out his Western trousers and tie which lay pressed under his mattress. Several places in his face skin were cut due to the shaving, but his whole face shone with a glow."

HAPPINESS IS HOT AND NOISY

(5) “......方先生有兴致也不妨来凑热闹, 欢迎的很。”(p. 114)

“...... join-hot-noisy, ......"

“......Mr. Fang, if you are interested in, why not come and join the fun? I'm very glad to have you."

HAPPINESS IS LIGHT (NOT HEAVY)

(6) “......走路时身体轻得好像地面在浮起来。”( p. 116)

“.......light......"

“......when he walked along, his body felt light as if the ground were rising."

HAPPINESS IS SWEET

(7) “他赔小心解释了半天, 她脸色和下来, 甜甜一笑道......” (p. 546)

“.......sweet-sweet-one-smile-say......"

"He spent a long time carefully explaining everything to her, then her facial expression softened, and she said with a sweet smile......"

HAPPINESS IS FULL

(8) “十二点多钟, 大家兴尽回船睡觉。” (p. 36)

“.......spirit-empty......”

"Around twelve o'clock, everyone enjoyed themselves to the full and went back to the ship to sleep."

HAPPINESS IS A GAME

(9) “幸而这桥也有走完的时候, 孙小姐回脸, 胜利地微笑。”( p. 290)

"......triumphantly-smile"

"Fortunately, they walked to the end of the bridge. Miss Sun turned her face and smiled triumphantly." 


\section{HAPPINESS IS VITALITY}

(10) “李先生本来像冬搵的冷血动物, 给顾先生当众恭维得春气入身, 蠕蠕欲活。” (p. 282)

“......spring-gas-enter-body, move-move-ready-live"

"Mr Li originally seemed like a cold-blooded animal in hibernation, but Mr Gu's praise in front of everyone made him feel the warmth of spring, and he became active with the life signs."

\section{HAPPINESS IS UNITY}

(11) “那女人的同乡都和着她欢笑。”(p. 302)

“..... join-she-happy-smile"

"The woman's country fellows all joined her in happy smiles."

\section{HAPPINESS IS SOFT}

(12) “柔嘉泪渍的脸温柔一笑道......” (p. 576)

“.......warm-soft-one-smile-say......."

"Roujia's tear-stained face became soft, and she said with a smile ......"

HAPPINESS IS LOOSE

(13) “鸿渐听她口气松动, 赔笑说: “一切燋我面上, 受点委屈。” ” (p. 614)

“...... tone-loose-move......"

"Hongjian heard her tone became loosened, he smiled and said, "For my sake, suffer a little injustice."

\section{HAPPINESS IS PRESSURE}

(14) “鸿渐跟唐小姐说句话, 唐小姐忍不住笑出声来。” (p. 128)

\section{“.......bear-no-stay-smile-out-voice-come”}

"Hongjian said a few words to Miss Tang, and then Miss Tang can't hold up and burst out laughing."

\section{HAPPINESS IS A SUBSTANCE IN A CONTAINER}

(15) “因此恍然大悟, 撒谎往往是高兴快乐的流露, 也算是一种创造, 好比小孩子游戏里的自骗自。” (p. 404)

“.......happiness-joy-outpouring,

"Then he suddenly realized that lying was often an outpouring of happiness and joy as well as a kind of creativity, like the game of "cheating oneself" played by children."

\section{HEART IS A CONTAINER OF HAPPINESS}

(16) “禇慎明掩鼻把窗子全打开, 满脸鄙厌, 可是心里高兴, 觉得自己泼的牛奶, 给鸿渐的呕吐在同席的 记忆里冲掉了。”( p. 190-192)

“.......heart-inside-high-spirit, ......"

"Covering his nose by hand, Chu Shenming opened all the windows. Although an expression of scorn was in his face, he was happy inside when thinking that Hongjian's vomit had removed the incident of his spilt milk from everybody's mind."

(17) “鸿渐听得开心, 想这真是转运的消息, 向唐小姐求婚一定也顺利。” (p. 202)

“.......open-heart, ......"

"When hearing this, Hongiian was very happy. He thought this must be a sign of luck change, so he should have no trouble making a proposal to Miss Tang."

\subsection{Anger}

255 metaphorical expressions of anger in Fortress Besieged were found. Through my analysis, 26 typical conceptual metaphors were employed to conceptualize anger, which are listed in Table 2. 
Table 2. Typical conceptual metaphors of anger in Fortress Besieged

\begin{tabular}{ll}
\hline Target Domain & Source Domains \\
\hline & Qi [gas] \\
Fire & Up \\
Down & Red \\
Livid & Hot \\
Cold \\
Heavy \\
Silence \\
A natural force \\
A physical force \\
Burden \\
Pain \\
Tight \\
Hard \\
A game \\
Separation \\
An account \\
An inferior object \\
Spleen \\
Heart \\
Stomach \\
Eyes \\
Nose \\
Mouth \\
\hline
\end{tabular}

Following are some characteristic examples of how anger is conceptualized through these typical metaphors in Fortress Besieged:

ANGER IS QI [GAS]

(18) “谁知道十五钟以后, 表姐第三次来电话, 我有点生气了。” (p. 136)

“..... a little-give birth-qi(gas)......"

"Fifteen minutes later, my cousin called me for the third time, so I got a little angry."

(19) “她回卧室去, 适才的盛气全消灭了, 疲乏懊恼。” (p. 208)

“......flourishing-qi(gas)......"

"She returned to her bedroom. With the disappearance of the rage of a moment ago, she felt tired and remorseful."

ANGER IS FIRE

(20) “顾尔谦冒火, 连声质问他: “难道我们眼睛是瞎的? ” ” (p. 324)

“......emit-fire, ......"

"Gu Erqian was infuriated, so he asked the waiter repeatedly, "Do you think we're blind?"”

ANGER IS UP

(21) “气头上虽然以吵嘴为快, 吵完了, 他们都觉得疲乏和空虚, 像戏散场和酒醒后的心理。”( p. 622) "anger-head-up......"

"They found quarreling was a relief in angry, but when the quarrel was over, both of them felt tired and empty, just like the feeling of the end of an opera or wake-up from a drunken sleep."

ANGER IS DOWN

(22) “柔嘉沉着脸, 只当没听见。”(p. 588)

“.......sinking-face, ......."

"Roujia pulled a face, pretending not to have heard." 


\section{ANGER IS RED}

(23) “......鸿渐已经差愤得脸红了, 到小舅子把报拿来, 接过一看, 夹耳根、连脖子、经背脊红下去直到 脚跟。”(p. 60)

“...... shame-anger-face-red...... through-ears-neck-spine-red-down to-heels"

“......Hongjian's face turned red with shame and anger. By the time his brother-in-law brought him the newspaper, he had read it, and the redness had passed from his ears and neck down his spine to his heels."

ANGER IS LIVID

(24) “苏小姐铁青着脸道: “别胡说！怎么是偷的? ”” (p. 150)

“......iron-green-face......"

"Miss Su's face became livid and said, "Don't be ridiculous! How can that be called stealing?"”

ANGER IS HOT

(25) “......汪处厚明知太太并非说自己, 可是通身发热。” (p. 496)

“.......whole-body-send off-heat"

“.....Wang Chuhou knew his wife wasn't saying him, but his whole body felt hot."

ANGER IS COLD

(26) “苏小姐气得身上发冷。”(p.16)

“.......anger-body-send off-cold"

"Miss Su was so angry that her body felt cold."

ANGER IS HEAVY

(27) “柔嘉重顿着右脚的皮鞋跟道: “我偏要跟她讲......”” (p. 680)

“......heavy-stamp......"

"Roujia said with a heavy stamp of her right shoe heel, "I must talk to her......"

ANGER IS SILENCE

(28) “鸿渐生气不响, 她注视着他的脸, 笑说: “跟我生气了? ......”” (p. 548)

“........ anger-no-voice, ......”

"Angered, Hongjian kept silent. She looked at his face and said with a smile, "Are you angry at me? ......"”

ANGER IS A NATURAL FORCE

(29) “高松年一阵恼怒, 想: “打牌! 还要打牌! 总有一天, 闹到学生耳朵里去, 该警告老汪这几个人了。” (p. 524)

“.......one-wave-anger, ......."

"A wave of anger came over to Gao Songnian, and he thought, "Playing mahjong! Still playing mahjong! One day the students will know it. I should warn the group of Old Wang."

ANGER IS A PHYSICAL FORCE

(30) “走了几条马路, 气愤稍平。”(p. 682)

“......, anger-a little-calm down"

"After walking a few blocks, he felt his anger a little subsided."

ANGER IS BURDEN

(31) “鸿渐看了早不痛快, 更经不起这几句话: “好, 好! 我以后再跟你讲话, 我不是人。” (p. 414)

“...... more-bear-no-up......"

"Hongjian was already very uncomfortable at seeing this, and these few words were more than he can bear. "All right, all right! I'm not a human being if I talk with you later."'

ANGER IS PAIN

(32) “谁知道父亲快信来痛骂一顿。” (p. 18)

“......pain-curse-one-pause" 
"He was quite unexpected when seeing the express letter from his father, which gave him a severe scolding."

ANGER IS TIGHT

(33) “夫妇俩吵架, 给她听见了, 脸便绷得跟两位主人一样紧, 正眼不瞧鸿渐, 给他东西也只是一搡。” ( $\mathrm{p}$. 648)

“......face-then-stretch-like-two-masters-same-tight, ......"

"She overheard the couple's quarrel, and then her face stretched as tightly as her masters'. She didn't look Hongjian directly. When she gave him something, she just shoved it at him."

ANGER IS HARD

(34) “在街口燋见一部汽车, 认识是陆家的, 心里就鲠一鲠。”(p. 682)

“......stiff-one-stiff"

"At the entrance to the street, he noticed the Lu's car, and his heart stiffened."

ANGER IS A GAME

(35) “汪处厚这人不好打发, 李梅亭是老朋友, 老朋友总讲得开, 就怕他的脾气难对付, 难对付! ” (p. 380)

“......temper-hard-deal with, ......"

"Wang Chuhou was hard to tackle, whereas Li Meiting was an old friend and an old friend should always be more tolerant. However, he found the only worry was that Li's temper would be hard to deal with. Really hard to deal with!"

\section{ANGER IS SEPARATION}

(36) “......她也生气了, 在街上不好吵, 便说......头一扭, 潄下丈夫, 独自过街到电车站去了。” (p. 650-652)

“.......abandon-down-husband, ......”

“...... She was angry too. As starting a quarrel on the street wasn't good, she said...... With a toss of her head, she abandoned her husband and went across the street to the tram station by herself."

\section{ANGER IS AN ACCOUNT}

(37) “柔嘉自从鸿渐去后, 不舒服加上寂寞, 一肚子的怨气, 等等他不来, 这怨气放印子钱似的本上生利, 只等他回来了算账。”( p. 572)

“.......calculate-account"

"Since Hongjian left, Roujia was filled with resentment because of discomfort and loneliness. She waited and waited but he still hadn't come, so her resentment grew with an unusually quick rate, and she just waited for his return to settle accounts."

THE OBJECT OF ANGER IS AN INFERIOR OBJECT

(38) “她还骂你是木头, 说你头上戴不戴帽子都不知道。” (p. 508)

“.......curse-you-is-wood, ......”

"She also called you a block of wood and said you didn't even know whether you wore a hat on your head."

SPLEEN IS A CONTAINER OF ANGER

(39) “方鸿渐正不知怎样发脾气才好, 阿刘鬼魂似地出现了, 向鲍小姐要酒钱。” (p. 48)

“.......send off-spleen-gas......."

“Just at the moment when Fang Hongjian didn't know how to show his anger, A Liu appeared like a ghost and asked tips from Miss Bao."

HEART IS A CONTAINER OF ANGER

(40) “密雨里点灯大非易事, 火柴都湿了, 连划几根只引得心里的火直冒。” (p. 292)

“......heart-inside-fire-send up"

"Lightening a lamp in the heavy rain wasn't easy, as all the matches went damp. Striking several of the matches only made the fire inside send up."

STOMACH IS A CONTAINER OF ANGER

(41) “事后, 刘先生怪太太不该提起昆明做媒的事, 触动她一肚子的怨气。” (p. 470) 
“......one-stomach-anger"

"Afterwards, Mr. Liu blamed his wife for causing his sister's pent-up anger by mentioning the Kunming matchmaking affair."

EYES ARE THE CONTAINERS OF ANGER

(42) “鲍小姐眼迸火星道: “伺候吃饭的赏钱, 昨天早给了。你还要什么赏? 我房舱又不是你管的。” (p. 48) “......eyes-burst forth-fire-stars......"

“Miss Bao's eyes burst out sparks and she said, "I already tipped you yesterday. Why do you want tips again now? My cabin is out of your charge."'"

NOSE IS A CONTAINER OF ANGER

(43) “梅亭一言不发, 向椅子里坐下, 鼻子里出气像待开发的火车头。”(p. 384)

“.......nose-inside-outside-gas......"

"Meiting sat down on a chair and kept silent and his nostrils blowing out gas like a locomotive ready to pull out."

MOUTH IS A CONTAINER OF ANGER

(44) “这吵架没变严重, 因为不能到孙家去吵, 不能回方家去吵, 不宜在路上吵, 所以舌剑唇枪无用之地。” (p. 620)

“......tongue-sword-lips-gun......"

"The quarrel didn't become more serious because they couldn't go to the Suns to quarrel or to the Fangs to quarrel, or they couldn't quarrel on the street. Thus there was no place for them to cross verbal swords with each other."

\subsection{Sadness}

137 metaphorical expressions of sadness in Fortress Besieged were found. Through my analysis, 12 typical conceptual metaphors were employed to conceptualize sadness, which are listed in Table 3.

Table 3. Typical conceptual metaphors of sadness in Fortress Besieged

\begin{tabular}{ll}
\hline Target Domain & Source Domains \\
\hline & Down \\
& Dark \\
& Red \\
& Cold \\
& Heavy \\
& Sour \\
Sadness & Empty \\
& Pain \\
& Lack of vitality \\
& Lack of Qi \\
& Heart \\
& Eyes \\
\hline
\end{tabular}

Following are some characteristic examples of how sadness is conceptualized through these typical metaphors in Fortress Besieged:

\section{SADNESS IS DOWN}

(45) “掩抑着秘密再也压不住了: “唐小姐。”鸿渐垂首低声说。”( p. 250)

“....... down-head-low-voice......"

"The secret cannot be kept any longer. "Miss Tang." said Hongjian in a low voice."

SADNESS IS DARK

(46) “本来辛楣仿佛跟鸿渐同遭丧事, 竭力和他竞赛着阴郁沉肃的表情, 不敢让他独得伤心之名。” (p. 250) “......gloomy-solemn......" 
"At first, Xinmei and Hongiian both seemed to suffer the same misfortune. Xinmei tried his best to compete with his friend in the expression of pain and misery, not just letting Hongjian alone get a name for being brokenhearted."

\section{SADNESS IS RED}

(47) “.......说时, 眼圈微红。” (p. 594)

"....... little-red"

".......as she spoke, her eyes' rims reddened a little."

\section{SADNESS IS COLD}

(48) “拥挤里的孤寂, 热闹里的凄凉, 使他像许多住在这孤岛上的人, 心灵也仿佛一个无凑畔的孤岛。”( p. 626)

“....... dreary-cold, ......"

"The loneliness in the crowds and the sadness among the excitement made him feel like many of the people living on this isolated island, and his heart was also like an isolated island."

\section{SADNESS IS HEAVY}

(49) “鸿渐的心那一跳的沉重, 就好像货车卸货时把包裹向地下一掼, 只奇怪辛楣会没听见......” (p. 274)

“.......sink-heavy, ......"

"Hongjian's heart had a heavy thump, like a package unloaded from a truck hit the ground. He just wondered why Xinmei didn't hear that....."

\section{SADNESS IS SOUR}

(50) “她看得心溶化成苦水, 想一分钟后他再不走, 一定不顾笑话, 叫用人请他回来。”(p. 210)

“.......sour-water, ......."

"When she watched this, her heart melted into sour water. If he still stood there in one more minute, she thought, she would ask the maid to invite him back regardless of the ridicule of others."

\section{SADNESS IS EMPTY}

(51) “鸿渐一人站着, 怅然若失, 望柔嘉的背影在隔街人从里出没, 异常纤弱, 不知那儿来的怜惜和保护 之心, 也就赶过去。”(p. 652)

“.......sad-lost, ......"

"Hongjian stood there by himself, feeling sad and lost. When he watched Roujia's back, unusually delicate, appeared and disappeared in the crowds on the street, an inexplicable feeling of pity and protectiveness came to him, and he ran after her."

SADNESS IS PAIN

(52) “不过, 受她冷落还在其次, 只是这今昔之比使人伤心。” (p. 588-590)

"...... pain-heart"

"Being left out in the cold by her was in the next place; it was the contrast between the past and the present which hurt so much."

\section{SADNESS IS LACK OF VITALITY}

(53) “方鸿渐失神落魄, 一天看十几种报纸, 听十几次无线电报告, 疲乏垂绝的希望披沙拣金似的要在消 息罅缝里找个苏息处。”(p. 80)

“....... lose-spirit-fall-soul, ......”

"Fang Hongjian felt very sad, so he read dozens of newspapers and listened to dozens of radio reports every day. Exhausted hope, as if sifting sand for gold, tried to find a place to revive itself in the cracks of the news."

SADNESS IS LACK OF QI

(54) “吃早饭时, 今天下船的那几位都垂头丧气。(p. 48)

“....... down-head-lose-qi(gas)"

"When eating breakfast, those disembarking today were in low spirits." 


\section{HEART IS A CONTAINER OF SADNESS}

(55) “过些时, 他才像从昏厥里醒过来, 开始不住的心痛, 就像因蜷曲而麻木的四肢, 到伸直了血脉流通, 就觉得刺痛。”(p. 216)

“......heart-pain, ......"

"Some time later, he awoke as if from a faint. He began feeling a continuous pain in his heart, which was like the stabbing pain a person feels when his numb limbs are stretched out and the blood is once again circulating."

EYES ARE THE CONTAINERS OF SADNESS

(56) “这景色是鸿渐出国前看惯的, 可是这时候见了, 忽然心挤紧作痛, 眼酸得要流沮。” (p. 64)

"......eyes-sour-want-flow-tears"

"This was the scene familiar to Hongjian before he went abroad. But now when he saw it, his heart suddenly squeezed in pain and his eyes soured to tear."

5.4 Love

76 metaphorical expressions of love in Fortress Besieged were found. Through my analysis, 20 typical conceptual metaphors were employed to conceptualize love, which are listed in Table 4.

Table 4. Typical conceptual metaphors of love in Fortress Besieged

\begin{tabular}{ll}
\hline Target Domain & Source Domains \\
\hline & A valuable object \\
A social status \\
Up \\
Sweet \\
A game \\
Food \\
Proximity \\
A journey \\
A standard \\
Yuanfen \\
(Predestined relationship) \\
Unity \\
An illness \\
A physical force \\
Drinking vinegar \\
Hot \\
Hire \\
A net \\
Silk \\
Heart \\
Eyes \\
\hline
\end{tabular}

Following are some characteristic examples of how love is conceptualized through these typical metaphors in Fortress Besieged:

LOVE IS A VALUABLE OBJECT

(57) “那时苏小姐把自己的爱情看得太名贵了, 不肯随便施与。” (p. 30)

“.......love-see-very-precious, .......”

"At that time Miss Su valued her love too highly to bestow it casually."

LOVE IS A SOCIAL STATUS

(58) “而今她身为女博士, 反觉得崇高的孤独, 没有人敢攀上来。”( p. 30)

“.......climb-up-come"

"Now she was a woman Ph.D., but she had a feeling of lofty loneliness, which made nobody dare to climb up." 


\section{LOVE IS UP}

(59) “悲剧里的恋爱大多数是崇高的浪漫, 她也觉得结婚以前, 非有伟大的心灵波折不可。” (p. 474)

“.......lofty-high-romance,......"

"Love in tragedies, in most cases, was loftily romantic. She also felt that before marriage there must be great mental twists and turns."

\section{LOVE IS SWEET}

(60) “她又说老式男女要好得像鸿渐跟苏小姐那样......只怕甜头吃完了, 结婚后反而不好。” (p. 202)

“.......sweet-head......"

"She said further that a traditional couple as intimate as Hongjian and Miss Su were ...... once the initial sweetness was over, things didn't turn out well after marriage."

\section{LOVE IS A GAME}

(61) “他不知道女人在恋爱胜利快乐的时候, 全想不到那些事的, 要有了疑惧, 才会要求男人赶快订婚结

婚, 爱情好有保障。”(p. 196-198)

“.......love-triumph-joy......”

"He didn't know the fact that when women are in the joy and triumph of love, they never think of those things. Until some doubts rise, they will demand the man to do the engagement and marriage in order to have their love safeguarded."

(62) “想来这是一切女人最可夸傲的时候, 看两个男人为她争斗。”( p. 110)

“....... for-she-fight"

"Fang Hongjian thought that two men fighting for her must be a woman's proudest moment."

\section{LOVE IS FOOD}

(63) “方鸿渐和鲍小姐不说话, 并肩踱着。一个大浪把船身晃得利害, 鲍小姐也站不稳, 方鸿渐勾住她腰,

傍了栏杆不走, 鮸嘴似地吻她。”(p. 34)

“......hungry-mouth-kiss-she"

"Fang Hongiian and Miss Bao walked side by side in silence. A big wave made the ship shake violently, so Miss Bao didn't stand still. Fang then held her waist, and leaning against the handrail, he kissed her hungrily."

\section{LOVE IS PROXIMITY}

(64) “鸿渐也摇头不说, 这更显得他跟唐小姐两口儿平分着一个秘密。”(p. 128)

“.......sharing-one-secret"

"Hongjian also shook his head and said nothing, which more clearly showed that he and Miss Tang were sharing a secret."

\section{LOVE IS A JOURNEY}

(65) “从恋爱到白头偕老, 好比一串葡萄, 总有最好的一颗, 最好的只有一颗, 留着做希望, 多少好? ” (p. 546)

"from-love-to-white head-together-old, ......"

"From falling in love to growing old together, it's like a bunch of grapes, which always has one best grape. The best one is the only one, so it is often left to the end as a hope. Isn't that good?"

\section{LOVE IS A STANDARD}

(66) “母亲不服气道: “咱们鸿渐也是个博士, 不输给她, 为什么配不过她? ”” (p. 68)

“.......match-no-over-her"

"His mother protested, "Our Hongjian is also a Ph.D., not inferior to her, so why not a good match for her?"

LOVE IS YUANFEN

(67) “柔嘉心慰道: “...... 这是不是所谓“缘分”, 两个陌生人偶然见面, 慢慢地要好? ”” (p. 596)

“......'Yuanfen' (predestined relationship), .......” 
“Roujia consoled herself, “.......isn't this what is called 'Yuanfen': two strangers meet by chance and fall in love slowly?"”

\section{LOVE IS UNITY}

(68) “有人说这是高松年开的玩笑, 存心拆开他们俩。”(p. 542)

“.......break apart-them-both"

"Someone said this was a joke played by Gao Songnian: cherishing certain intentions to break both of them apart."

\section{LOVE IS AN ILLNESS}

(69) “辛楣道: “你这人太不坦白! 咱们现在是同病相怜, 我失恋, 你也失恋, 当着我, 你不用装假挣面子。 难道你就不爱苏小姐? ” ” (p. 250)

“.......same-illness-mutually-pity, ......."

"Xinmei said, "You're not honest! We are now fellow sufferers having mutual sympathy. I'm crossed in love and so are you. You don't have to pretend and try to save face in front of me. Don't you love Miss Su?"

LOVE IS A PHYSICAL FORCE

(70) “为什么爱情会减少一个人心灵的抵抗力, 使人变得软弱, 被摆布呢? ” (p. 130)

“.......reduce-one-person-mental-resistance, ......."

"Why does love relieve one's mental resistance and make one feel so weak that one can be easily manipulated?"

LOVE IS DRINKING VINEGAR

(71) “鸿渐忽然明白, 这姓赵的对自己无礼, 是在吃醋, 当自己是他的情敌。” (p. 110)

“...... drink-vinegar, ......"

"Hongjian suddenly understood that Zhao's rudeness to him had sourced from drinking vinegar (being jealous because of love), for Zhao had taken him as his love rival."

LOVE IS HOT

(72) “他对自己解释, 热烈的爱情到订婚早已是顶点, 婚一结一切了结。”(p. 546)

“.......hot-strong......"

"He explained to himself that passionate love usually reached its peak at the time of engagement and was over after marriage."

\section{LOVE IS FIRE}

(73) “老头子恋爱听说像老房子着了火, 烧起来没有救的。” (p. 570)

“.......burn-up-come......”

"Old men's love was said to be like an old house on fire. Once it started burning, there was no way saving it."

LOVE IS A NET

(74) “他忽然省悟这情势太危险, 今天不该自投罗网, 后悔无及。”(p. 196)

“......oneself-throw-net, ......”

"He suddenly realised how embarrassing the situation was. He shouldn't have delivered himself into her hands that day but it was too late to repent."

LOVE IS SILK

(75) “他只等机会向她声明并不爱她, 恨自己心肠太软, 没有快刀斩乱丝的勇气。”(p. 164)

“.......sharp-knife-cut-tangled-silk......"

"He was just waiting for a chance to tell her that he did not love her, but he hated himself in that he was so tenderhearted that he could not be courageous to cut a tangled skein of silk with a sharp knife (make a lightning decision)."

\section{HEART IS A CONTAINER OF LOVE}

(76) “并非因为她年龄大了; 她比鲍小姐大不了多少, 并且当着心爱的男人, 每个女人都有返老还童的绝 技。”(p. 52) 
"......heart-love......"

"It's not that her age was older; she wasn't much older than Miss Bao. Besides, in front of their beloved men, every woman has the unique skill of rejuvenation."

EYES ARE THE CONTAINERS OF LOVE

(77) “鸿渐本想说：“其实全没有关系, ”可是在苏小姐抚爱的眼光下，这话不能出口。” (p. 166)

“....... doting-eyes-light......"

“Hongjian was going to say: it doesn't matter at all, but under Miss Su's doting gaze, he didn't say it out."

\section{Discussion}

Based on the above analysis, the following observations are noteworthy.

6.1 Common Source Domains of Emotion Metaphor in Fortress Besieged

Kövecses (2000) finds that there are 13 common source domains of metaphor, which are listed in Table 5.

Table 5. Common source domains of metaphor

\begin{tabular}{l}
\hline Common Source Domains of Metaphor \\
\hline The human body \\
Animals \\
Buildings and construction \\
Games and sport \\
Cooking and food \\
Light and darkness \\
Health and illness \\
Plants \\
Machines and tools \\
Money and economic transactions \\
Heat and cold \\
Force \\
Movement and direction
\end{tabular}

According to my analysis, there are 18 common source domains of emotion metaphor in Fortress Besieged, which are shown in Table 6.

Table 6. Common source domains of emotion metaphor in Fortress Besieged

\begin{tabular}{l}
\hline Common Source Domains of Emotion Metaphor in Fortress Besieged \\
\hline Orientation \\
Colors \\
Weight \\
Tightness \\
Tastes \\
Health and illness \\
Sound volume \\
Cooking and food \\
Grades \\
Light and darkness \\
Heat and cold \\
Softness \\
Quantity \\
Games and sport \\
Distance \\
Force \\
Money and economic transactions \\
The human body
\end{tabular}




\subsection{ANGER IS QI}

“ANGER IS QI” is frequently used to conceptualize anger in Fortress Besieged. Here, I think the “阴阳学说” (Yin-yang Theory) of Chinese philosophy (YYT) and the “传统中医理论” (Traditional Chinese Medicine Theory) (TCMT) play an important role.

YYT thinks that all things in the universe are governed by the law of the unity of two opposite but complementary aspects, “阴” (Yin: feminine) and “阳” (Yang: masculine) (Z. Chen, 1989a). According to YYT, "negative, static and weak" are the typical characteristics of Yin, whereas "positive, dynamic and strong" are the typical characteristics of Yang. Some typical opposites and binary properties of Yin and Yang are listed in Tables 7 and 8 (based on Z. Chen, 1989a, p. 997).

Table 7. Some typical opposites of Yin and Yang

\begin{tabular}{cccccccc}
\hline Properties & \multicolumn{7}{c}{ Opposites } \\
\hline Yin & Moon & Land & Water & Cold & Woman & Night & Winter \\
Yang & Sun & Heaven & Fire & Hot & Man & Day & Summer \\
\hline
\end{tabular}

Table 8. Some typical binary properties of Yin and Yang

\begin{tabular}{ccccccc}
\hline \multirow{2}{*}{ Properties } & \multicolumn{5}{c}{ Classifications } \\
\cline { 2 - 6 } & Orientation & Temperature & Humidity & Light intensity & Physical state & Quantity \\
\hline Yin & Down/Internal & Cool/Cold & Wet & Dim & Fluid & Less \\
Yang & Up/External & Warm/Hot & Dry & Bright & Gas & More \\
\hline
\end{tabular}

From the above tables, we can see that "Hot" and "Qi (Gas)" belong to the group of Yang. As "body feels hot" is an important physiological effect of anger, it is obvious why "ANGER IS QI" is so dominant in conceptualizing anger in Fortress Besieged.

According to TCMT, the human body is composed of three basic substances: Qi (Gas), Xue (Blood), and Jinye (Body fluids other than blood), which serve to maintain the normal activities of the human body (Z. Chen, 1989b; Zhang, Wang \& Shi, 1990a). Z. Chen (1989b) further notes that Qi is "the moving but invisible, nutritive substance which functions as the motive power for the physiological movement of internal organs" (p. 1010), and it is Qi that promotes the formation and circulation of blood and the metabolism of body fluids as well. Furthermore, Zhang, Wang and Shi (1990a) states that TCMT thinks a sudden, violent or long-term emotion will cause the functional disorder and derangement of viscera, bowels and Qi. This may well be the other motivation why anger is so closely related to Qi in Fortress Besieged.

\subsection{Human Body Organs as Source Domains}

Human body organs (e.g., eyes, nose, mouth, heart, spleen, and stomach) are used as the source domains of emotion metaphors in Fortress Besieged. Here, I think the “五行学说” (Theory of Five Elements) (TFE) of Chinese medicine can provide an explanation.

TFE proposes that the universe is composed of five basic elements: “金” (metal), “木” (wood), “水” (water), “火” (fire) and “土” (earth), which can be used to classify things according to their properties and relations to other things. The five elements are in a relation of mutual promotion and restraint, through which the balance of the universe is achieved (Z. Chen, 1989a). Taking "wood, fire, earth, metal, water" as a basic framework, TFE divides natural phenomena and the human body into five basic categories according to their properties, function and relationship with others. Table 9 (based on Z. Chen, 1989a, p. 1000) illustrates how natural phenomena, human body organs and human emotions are classified into five categories headed by TFE. 
Table 9. Five categories of theory of five elements

\begin{tabular}{|c|c|c|c|c|c|c|c|}
\hline \multicolumn{3}{|c|}{ Natural Phenomena } & \multirow{2}{*}{$\begin{array}{c}\text { Five } \\
\text { Elements }\end{array}$} & \multicolumn{4}{|c|}{ The Human Body } \\
\hline $\begin{array}{c}\text { Five } \\
\text { Climates }\end{array}$ & $\begin{array}{c}\text { Five } \\
\text { Seasons }\end{array}$ & $\begin{array}{c}\text { Five } \\
\text { Locations }\end{array}$ & & $\begin{array}{c}\text { Five } \\
\text { Zang (Viscera) }\end{array}$ & $\begin{array}{c}\text { Five } \\
\text { Fu (Bowels) }\end{array}$ & $\begin{array}{c}\text { Five } \\
\text { Sense Organs }\end{array}$ & $\begin{array}{c}\text { Five } \\
\text { Emotions }\end{array}$ \\
\hline Windy & Spring & East & Wood & Liver & Gallbladder & Eyes & Anger \\
\hline Hot & Summer & South & Fire & Heart & Small intestine & Tongue & Happiness \\
\hline Wet & $\begin{array}{c}\text { Late } \\
\text { summer }\end{array}$ & Center & Earth & Spleen & Stomach & Mouth & Anxiety \\
\hline Dry & Autumn & West & Metal & Lung & Large intestine & Nose & Sadness \\
\hline Cold & Winter & North & Water & Kidney & Urinary bladder & Ears & Fear \\
\hline
\end{tabular}

According to TFE, items classified into the same category are related to each other and have the same mutual promotion and restraint relations with the objects in the neighbouring categories. For instance, a disease in the liver affects the eyes and the emotion of anger. Extreme anger is considered to be harmful to the liver. Such classification and correspondence in terms of the five elements clarify the mutual relationship between the human body, senses and emotions. As pointed out by Zhang, Wang and Shi (1990b, p. 28), "human mental activities are closely related with the viscera. Certain viscus is related to certain emotional activity: the liver is related to anger, the heart to joy, the spleen to anxiety, the lung to melancholy and the kidney to fear. Only by acting on the corresponding viscera can the environmental emotional stimuli evoke specific emotional responses". These relations help to explain why Fortress Besieged uses human body organs in conceptualizing emotions.

\subsection{Agricultural Products as Source Domains}

Agricultural products (e.g., vinegar, silk, and net) are used as the source domains to conceptualize love in Fortress Besieged. According to Kövecses (2002, p. 187),

"The natural and physical environment shapes a language, primarily its vocabulary, in an obvious way; consequently, it will shape the metaphors as well. Given a certain kind of habitat, speakers living there will be attuned (most subconsciously) to things and phenomena that are characteristic of that habitat; and they will make use of these things and phenomena for the metaphorical comprehension and the creation of their own conceptual universe."

China is a country with a distinct geography: vast ocean to its east, valleys and hillocks to its south, desert to its northwest, and Qinghai-Tibetan Plateau to its southwest. Though the adequate living space is blessed with natural resources, the half-isolated terrain keeps China from outward exploration. In this case, a continental farming culture is nurtured with people toiling in field from dawn to dusk as daily routine. Throughout the five-thousand-year's Chinese civilization, agriculture has always occupied a key position in social structure. For example, Chinese people plant mulberry trees and raise silkworms to produce silk and make clothes; vinegar, made by crops, is one of the indispensable condiments in Chinese food. This environment could justify why Qian used a number of agricultural products as the source domains to conceptualize love in Fortress Besieged.

\section{Conclusions}

In this article, I have studied how emotions are conceptualized through metaphors in Fortress Besieged. Through my analysis, I find CMT is a powerful tool for conceptualizing the abstract concepts not only in spoken language but also in the literary text, in this case, the novel Fortress Besieged. Emotions, which are abstract in nature, are largely conceptualized through metaphors grounded in bodily experiences in Fortress Besieged. Most of the conceptual metaphors of emotions are ontological and structural, and some are orientational. This empirical result supports Lakoff and Johnson's claim that "[t]here are systematic correlates between our emotions and our sensory-motor experiences" (Lakoff \& Johnson, 1980, p. 58).

A range of typical conceptual metaphors of emotions in Fortress Besieged are found, such as "HAPPINESS IS UP", "HAPPINESS IS LIGHT", "ANGER IS QI", "ANGER IS DOWN", "SADNESS IS EMPTY", "SADNESS IS PAIN", "LOVE IS UP", "LOVE IS DRINKING VINEGAR" and "HEART IS A CONTAINER OF EMOTIONS". However, I find that living environment and cultural models play a significant role in selecting one source domain over another when conceptualizing emotions through metaphors in Fortress Besieged. For example, "Qi" takes a fairly higher proportion than any other source domains in conceptualizing anger. I suggest that it is the cultural models of YYT and TFE of Chinese philosophy and medicine that motivate its high frequency. This finding confirms the claim of Kövecses (1999), Quinn (1991) and Yu (1998) that 
"cultural models play a significant role in constituting our understanding of the world and constraining the selection of metaphors" (Yu, 1998, p. 44).

\section{References}

Allan, K. (1995). The anthropocentricity of the English word(s) back. Cognitive Linguistics, 6, 11-31. http://dx.doi.org/10.1515/cogl.1995.6.1.11

Athanasiadou, A., \& Tabakowska, E. (Eds.). (1998). Speaking of Emotions: Conceptualization and Expression. Berlin/New York: Mouton de Gruyter. http://dx.doi.org/10.1515/9783110806007

Barcelona, A. (1986). On the concept of depression in American English: A cognitive approach. Revista Canaria de Estudios Ingleses, 12, 7-33.

Barcelona, A. (1995). Metaphorical models of romantic love in Romeo and Juliet. Journal of Pragmatics, 24, 667-688. http://dx.doi.org/10.1016/0378-2166(95)00007-F

Barcelona, A. (2002). Clarifying and applying the notions of metaphor and metonymy within cognitive linguistics: an update. In R. Dirven \& R. Porings (Eds.), Metaphor and Metonymy in Comparison and Contrast (pp. 207-277). Berlin/New York: Mouton de Gruyter. http://dx.doi.org/10.1515/9783110219197.207

Barcelona, A. (Ed.). (2000). Metaphor and Metonymy at the Crossroads: A Cognitive Perspective. Berlin/New York: Mouton de Gruyter.

Bowles, W. (2006). Psychology and Emotion: Understanding How to Deal with Life. Washington: PublishAmerica.

Chen, J. (2007). A Contrastive Study of Metaphors between English and Chinese. Shanghai: Xuelin Press.

Chen, Z. (1989a). Yin yang wu xing (Theories of yin and yang, and of the five elements). In W. Jin, C. Meng, J. Zhu, S. Xu, H. Chen, S. Chen, Z. Shen, X. Wu, X. Li, S. Li, S. Yu, J. Zhang, S. Hu, J. Xu, Z. Xu, D. Sheng, \& X. Ji (Eds.), Jiating yixue quanshu (pp. 997-1002). Shanghai: Shanghai Science and Technology Press.

Chen, Z. (1989b). Zang xiang (Theory of internal organs). In W. Jin, C. Meng, J. Zhu, S. Xu, H. Chen, S. Chen, Z. Shen, X. Wu, X. Li, S. Li, S. Yu, J. Zhang, S. Hu, J. Xu, Z. Xu, D. Sheng, \& X. Ji (Eds.), Jiating yixue quanshu (pp. 1003-1012). Shanghai: Shanghai Science and Technology Press.

D'Andrade, R. (1995). The Development of Cognitive Anthropology. New York: Cambridge University Press. http://dx.doi.org/10.1017/CBO9781139166645

Ekman, P. (1999). Basic emotions. In T. Dalgleish and M. Power (Eds.), Handbook of Cognition and Emotion (pp. 45-60). Chichester: John Wiley and Sons.

Fludernik, M. (Ed.) (2011). Beyond Cognitive Metaphor Theory: Perspective on Literary Metaphor. New York: Routledge.

Gibbs, R. (1994). The Poetics of Mind: Figurative Thought, Language, and Understanding. New York: Cambridge University Press.

Gibbs, R. (2006). Metaphor interpretation as embodied simulation. Mind \& Language, 21, 434-458. http://dx.doi.org/10.1111/j.1468-0017.2006.00285.x

Gibbs, R., \& Steen, G. (Eds.) (1999). Metaphor in Cognitive Linguistics. Amsterdam: John Benjamins. http://dx.doi.org/10.1075/cilt.175

Goldie, P. (2000). The emotions: A philosophical exploration. New York: Oxford University Press.

Goldie, P. (2010). The Oxford Handbook of Philosophy of Emotion. New York: Oxford University Press.

Heberlein, A. \& Adolphs, R. (2007). Neurobiology of emotion recognition: Current evidence for shared substrates. In E. Harmon-Jones \& P. Winkielman (Eds.), Fundamentals of social neuroscience (pp. 31-55). New York: Guilford Press.

Hsia, C. (1999). A History of Modern Chinese Fiction. Bloomington: Indiana University Press.

Johnson, M. (1987). The Body in the Mind: The Bodily Basis of Meaning, Imagination, and Reason. Chicago: University of Chicago Press.

Kelly, J., \& Mao, N. (2003). Fortress Besieged. Beijing: Foreign Language Teaching and Research Press. 
King, B. (1989). The Conceptual Structure of Emotional Experience in Chinese. PhD Dissertation, The Ohio State University, USA.

Kövecses, Z. (1986). Metaphors of Anger, Pride, and Love: A Lexical Approach to the Structure of Concepts. Amsterdam: John Benjamins. http://dx.doi.org/10.1075/pb.vii.8

Kövecses, Z. (1988). The Language of Love: The Semantics of Passion in Conversational English. Lewisburg, PA: Bucknell University Press.

Kövecses, Z. (1990). Emotion Concepts. New York: Springer-Verlag. http://dx.doi.org/10.1007/978-1-4612-3312-1

Kövecses, Z. (1991). Happiness: A definitional effort. Metaphor and Symbolic Activity, 6(1), 29-46. http://dx.doi.org/10.1207/s15327868ms0601_2

Kövecses, Z. (1995a). Metaphor and the folk understanding of anger. In J. Russell, J. Fernández-Dols, A. Manstead, \& J. Wellenkamp (Eds.), Everyday Conceptions of Emotion (pp. 49-71). Dordrecht: Kluwer. http://dx.doi.org/10.1007/978-94-015-8484-5_3

Kövecses, Z. (1995b). Anger: Its language, conceptualization, and physiology in the light of cross-cultural evidence. In J. Taylor \& R. MacLaury (Eds.), Language and the Cognitive Construal of the World (pp. 181-196). Berlin: Mouton de Gruyter. http://dx.doi.org/10.1515/9783110809305.181

Kövecses, Z. (1998). Are there any emotion-specific metaphors. In A. Athanasiadou \& E. Tabakowska (Eds.), Speaking of Emotions: Conceptualization and Expression (pp. 127-152). Berlin: Mouton de Gruyter. http://dx.doi.org/10.1515/9783110806007.127

Kövecses, Z. (1999). Metaphor: Does it constitute or reflect cultural models? In R. Gibbs \& G. Steen (Eds.), Metaphor in Cognitive Linguistics (pp. 167-188). Amsterdam: John Benjamins. http://dx.doi.org/10.1075/cilt.175.10kov

Kövecses, Z. (2000). Metaphor and Emotion: Language, Culture, and Body in Human Feeling. Cambridge: Cambridge University Press.

Kövecses, Z. (2002). Metaphor: A Practical Introduction. New York: Oxford University Press.

Kövecses, Z. (2005). Metaphor in Culture: Universality and Variation. Cambridge: Cambridge University Press. http://dx.doi.org/10.1017/CBO9780511614408

Kövecses, Z. (2008). The Conceptual Structure of Happiness. In H. Tissari, A. Pessi, \& M. Salmela (Eds.), Happiness: Cognition, Experience, Language (pp. 131-143). Helsinki: Helsinki Collegium for Advanced Studies, University of Helsinki.

Lakoff, G. (1987). Women, Fire, and Dangerous Things: What Categories Reveal about the Mind. Chicago: University of Chicago Press. http://dx.doi.org/10.7208/chicago/9780226471013.001.0001

Lakoff, G. (1990). The invariance hypothesis: Is abstract reason based on image-schemas? Cognitive Linguistics, 1, 39-75. http://dx.doi.org/10.1515/cogl.1990.1.1.39

Lakoff, G., \& Johnson, M. (1980). Metaphors We Live By. Chicago: University of Chicago Press.

Lakoff, G., \& Kövecses, Z. (1987). The cognitive model of anger inherent in American English. In D. Holland \& N. Quinn (Eds.), Cultural Models in Language and Thought (pp. 195-221). Cambridge: Cambridge University Press. http://dx.doi.org/10.1017/CBO9780511607660.009

Lakoff, G., \& Turner, M. (1989). More Than Cool Reason: A Field Guide to Poetic Metaphor. Chicago: University of Chicago Press. http://dx.doi.org/10.7208/chicago/9780226470986.001.0001

Lan, C. (2005). Cognitive Linguistics and Metaphor Research. Beijing: Foreign Language Teaching and Research Press.

LeDoux, J. (1986). The neurobiology of emotion. In J. LeDoux \& W. Hirst (Eds.), Mind and brain: Dialogues in cognitive neuroscience (pp. 301-354). Cambridge: Cambridge University Press.

LeDoux, J. (1996). The Emotional Brain: The Mysterious Underpinnings of Emotional Life. New York: Touchstone.

Lutz, C. (1988). Unnatural Emotions: Everyday Sentiments on a Micronesian Atoll and Their Challenge to Western Theory. Chicago: University of Chicago Press. 
Lutz, C., \&White, G. (1986). The anthropology of emotions. Annual Review of Anthropology, 15, 405-436. http://dx.doi.org/10.1146/annurev.an.15.100186.002201

Milton, K., \& Svašek, M. (2005). Mixed Emotions: Anthropological Studies of Feeling. Oxford: Berg Publishers.

Niemeier, S., \& Dirven, R. (Eds.). (1997). The Language of Emotions: Conceptualization, Expression, and Theoretical Foundation. Amsterdam: John Benjamins. http://dx.doi.org/10.1075/z.85

Ortony, A., Clore, G., \& Collins, A. (1988). The Cognitive Structure of Emotions. Cambridge: Cambridge University Press. http://dx.doi.org/10.1017/CBO9780511571299

Palmer, G., \& Occhi, D. (Eds.). (1999). Languages of Sentiment Cultural Constructions of Emotion Substrates. Amsterdam: John Benjamins. http://dx.doi.org/10.1075/aicr.18

Plutchik, R. (1994). The Psychology and Biology of Emotion. London: Harper Collins.

Pragglejaz Group. (2007). MIP: A method for identifying metaphorically used words in discourse. Metaphor and Symbol, 22(1), 1-39. http://dx.doi.org/10.1080/10926480709336752

Qian, Z. (2003/1947). Wei Cheng. Beijing: The People's Literature Publishing House.

Quinn, N. (1991). The cultural basis of metaphor. In J. Fernandez (Ed.). Beyond Metaphor: The Theory of Tropes in Anthropology (pp. 56-93). Stanford: Stanford University Press.

Solomon, R. (1993). The philosophy of emotions. In M. Lewis \& J. Haviland (Eds.), Handbook of emotions (pp. 3-15). New York: Guilford.

Tissari, H. (2001). Metaphors we love by: On the cognitive metaphors of love from the 15 th century to the present. Studia Anglica Posnaniensia, 36, 217-242.

Tissari, H. (2006a). Conceptualizing shame: Investigating uses of the English word shame, 1418-1991. H. Tissari, R. McConchie, O. Timofeeva, \& T. Säily (Eds.), Selected Proceedings of the 2005 Symposium on New Approaches in English Historical Lexis (HEL-LEX) (pp. 143-154). Somerville, MA: Cascadilla Proceedings Project.

Tissari, H. (2006b). Justified pride? Metaphors of the word pride in English language corpora, 1418-1991. Nordic Journal of English Studies, 5(1), 15-49.

Tissari, H. (2008). Happiness and joy in corpus contexts: A cognitive semantic analysis. In H. Tissari, A. Pessi, \& M. Salmela (Eds.), Happiness: Cognition, Experience, Language (pp. 144-174). Helsinki: Helsinki Collegium for Advanced Studies, University of Helsinki.

Tissari, H. (2010). Love, metaphor and responsibility: Some examples from Early Modern and Present-Day English corpora. In G. Low, Z. Zazie, A. Deignan, \& L. Cameron (Eds.), Researching and Applying Metaphor in the Real World (pp. 125-143). Amsterdam: John Benjamins. http://dx.doi.org/10.1075/hcp.26.09tis

Turner, M. (1987). Death is the Mother of Beauty: Mind, Metaphor, Criticism. Chicago: University of Chicago Press.

Wierzbicka, A. (1992). Talking about emotions: Semantics, culture and cognition. Cognition and Emotion, 6(3/4), 285-319. http://dx.doi.org/10.1080/02699939208411073

Wierzbicka, A. (1998). "Sadness" and "anger" in Russian: The non-universality of the so-called basic human emotions. In A. Athanasiadou \& E. Tabakowska (Eds.), Speaking of Emotions: Conceptualization and Expression (pp. 3-28). Berlin: Mouton de Gruyter. http://dx.doi.org/10.1515/9783110806007.3

Wierzbicka, A. (1999). Emotions across Languages and Culture: Diversity and Universals. Cambridge: Cambridge University Press. http://dx.doi.org/10.1017/CBO9780511521256

Wierzbicka, A. (2009). Language and metalanguage: Key issues in emotion research. Emotion Review, 1(1), 3-14. http://dx.doi.org/10.1177/1754073908097175

$\mathrm{Yu}, \mathrm{N}$. (1995). Metaphorical expressions of anger and happiness in English and Chinese. Metaphor and Symbolic Activity, 10(2), 59-92. http://dx.doi.org/10.1207/s15327868ms1002_1

Yu, N. (1998). The Contemporary Theory of Metaphor: A Perspective from Chinese. Amsterdam: John Benjamins. http://dx.doi.org/10.1075/hcp.1

Yu, N. (2002). Body and emotion: Body parts in Chinese expression of emotion. Pragmatics and Cognition, 10(1-2), 341-367. http://dx.doi.org/10.1075/pc.10.1-2.14yu 
Zhang, E., Wang, M., \& Shi, L. (Eds.). (1990a). Basic Theory of Traditional Chinese Medicine (I). Shanghai: Publishing House of Shanghai University of Traditional Chinese Medicine.

Zhang, E., Wang, M., \& Shi, L. (Eds.). (1990b). Basic Theory of Traditional Chinese Medicine (II). Shanghai: Publishing House of Shanghai University of Traditional Chinese Medicine.

Zhang, L. (1985). The 'Tao' and the 'Logos': Notes on Derrida's Critique of Logocentrism. Critical Inquiry, 11(3), 385-398. http://dx.doi.org/10.1086/448294

\section{Note}

Note 1. In this paper, I used The Contemporary Chinese Dictionary (Chinese-English Edition) as a reference, which is the most authoritative and widely used contemporary Chinese dictionary in China and published by Beijing: Foreign Language Teaching and Research Press in 2002.

\section{Copyrights}

Copyright for this article is retained by the author(s), with first publication rights granted to the journal.

This is an open-access article distributed under the terms and conditions of the Creative Commons Attribution license (http://creativecommons.org/licenses/by/3.0/). 